\title{
Evidence of Ambiguous Differentiation and mTOR Pathway Dysregulation in Subependymal Giant Cell Astrocytoma
}

\author{
Subependimal Dev Hücreli Astrositomlarda Belirgin Olmayan \\ Farklılaşma ve mTOR Yolağı Bozuklukları
}

\author{
Brad D BARROWS', Martin J RUTKOWSKI ${ }^{2}$, Şakir Humayun GÜLTEKIN ${ }^{3}$, Andrew T PARSA ${ }^{2}$, Tarık TIHAN ${ }^{1}$ \\ Departments of ${ }^{1}$ Pathology and ${ }^{2}$ Neurosurgery, University of California San Francisco, SAN FRANCISCO, USA \\ ${ }^{3}$ Department of Pathology, Oregon Health Sciences University, PORTLAND, USA
}

\begin{abstract}
Objective: The exact cell of origin of subependymal giant cell astrocytoma is debated but most currently consider the tumor in the astrocytic category. Mutations and subsequent biallelic inactivation of TSC1 encoding hamartin, or TSC 2 encoding tuberin appear to be the underlying genetic aberrations. Inactivation leads to loss of proteins that inhibit mammalian target of rapamycin (mTOR) disrupting tightly regulated cell functions.
\end{abstract}

Material and Method: We analyzed the expression of tuberin and hamartin along with an array of neuroepithelial markers in 9 subependymal giant cell astrocytomas. In addition, RPS6 and 4EBP1 regulatory proteins that are downstream in the mTOR pathway were also evaluated.

Results: While hamartin and tuberin expression levels were relatively decreased compared to control tissue, this was not of particular practical use to detect the mutated gene since low levels of positivity could be detected throughout the central nervous system. As expected, the levels of RPS6 and 4EBP1 were increased, further confirming the activation of the mTOR pathway. GFAP was positive in 5 cases, while Synaptophysin positivity was found in all tumors. CD34 (a marker often observed in well differentiated glio-neuronal tumors), Olig2 (a nuclear marker present in most gliomas), IDH1 and IDH2 were entirely negative in all tumor cells. Ki67 (MIB-1) showed a low proliferation rate ranging from $2 \%$ to $8 \%$.

Conclusion: Staining with neuroepithelial markers supports the suggestion of ambiguous differentiation. Subependymal giant cell astrocytomas do not appear to have the typical expression profiles of astrocytic tumors, under which they have been classified.

Key Words: Subependymal giant cell astrocytoma, Hamartin, Tuberin, mTOR complex, IDH1, IDH2, Olig2

(Turk Patoloji Derg 2012, 28:95-103)

Received : 02.02.2012 Accepted : 02.03.2012
ÖZ

Amaç: Subependimal dev hücreli astrositom hücre kökeni kesin olarak belirli olmamasına karşın astrositik tümörler arasında sınıflandırılan bir tümördür. Subependimal dev hücreli astrositomlarda tipik genetik anomali Hamartin'i kodlayan TSC1 veya Tuberin'i kodlayan TSC2 genlerindeki mutasyon ve diğer alelin inaktivasyonudur. Bu genlerin inaktivasyonu "rapamisin'in memelilerdeki hedefi" olarak bilinen mTOR yolağı üzerinden hücrede sıkı biçimde kontrol edilen kritik işlevlerin bozulmasına neden olur.

Gereç ve Yöntem: Bu çalışmada, 9 subependimal dev hücreli astrositom olgusunda Tuberin ve Hamartin yanısıra nöroepitelyal belirteçlerin düzeylerini immünhistokimyasal yöntemlerle inceledik. Ayrıca mTOR yolağında yer alan RPS6 and 4EBP1 proteinlerinin de düzeylerini araştırdık.

Bulgular: Hamartin ve Tuberin antikorları normal dokuya oranla tümörlerde daha az boyansa da normale benzer düzeylerde bulunmaları genetik anomaliyi saptama açısından yarar sağlamadı. RPS6 ve 4EBP1 kuvvetli pozitifliğinin mTOR yolağının aktivasyonunu gösterdiği görüşünü destekledi. İmmünhistokimyasal çalışmalarda GFAP sadece beş olguda kuvvetli pozitif olarak saptandı. Sinaptofizin bütün olgularda pozitif boyama gösterdi. Glionöronal tümörlerde tipik olarak görülen CD34 pozitifliği bu olgularda saptanmadı. Ayrıca Olig2, IDH1 ve IDH2 immünhistokimyasal olarak tüm olgularda negatif olarak bulundu. Ki67 (MIB-1) boyanma indeksi \%2 ile \%8 arasında değişti.

Sonuç: Nöroepitelyal belirteçlerle boyanmanın astrositik dışı bir başkalaşıma kanıt oluşturduğu düşünüldü. Subependimal dev hücreli astrositom saf astrositik tümörledeki klasik immünhistokimyasal profile uymadığından bu tümörün astrositik grupta sınıflandırılmasının doğru olmama olasılığı bulunmaktadır.

Anahtar Sözcükler: Subependimal dev hücreli astrositoma, Hamartin, Tuberin, mTOR kompleksi, IDH1, IDH2, Olig2

Correspondence: Tarik TIHAN

Department of Pathology, University of California San Francisco, SAN FRANCISCO, USA

E-mail: tarik.tihan@ucsf.edu Phone: +001 4155149332 


\section{INTRODUCTION}

Subependymal giant cell astrocytomas (SEGAs) are benign, indolent, intraventricular tumors made up of large gemistocytic cells with an apparent astrocytic phenotype. SEGAs occur in association with tuberous sclerosis, most commonly in children and young adults. The Tuberous Sclerosis Complex (TSC) is an autosomal dominant syndrome that also occurs in many patients with no previous family history, indicating a high sporadic mutation rate for these genes (1). The disease manifests as multiple hamartomas, which form in the heart, brain, kidney and skin. The genes involved in tuberous sclerosis include TSC1 encoding the hamartin protein, and TSC2 encoding the tuberin protein. Mutations and subsequent biallelic inactivation of either TSC1 (located at 9q34) or TSC2 (located at 16p13) have been demonstrated in SEGAs (2). LOH more commonly involves TSC2 (57\%) compared to TSC1 (4\%); although $\mathrm{LOH}$ is less common in brain lesions (4\%), it is much more common in renal angiomyolipomas and cardiac rhabdomyomas (56\%) (35). Biallelic inactivation is suggested to lead to the loss of proteins that inhibit mammalian target of rapamycin (mTOR) disrupting a large number of tightly regulated cell functions $(6,7)$. Previous studies have shown that the inactivation of TSC1 or TSC2 genes can be demonstrated in numerous sporadic tumor types in multiple organ systems (8-10). Dysregulation of the mTOR pathway appears to be primarily due to TSC gene inactivation in SEGAs. Studies have illustrated the link between mTOR dysregulation and the phosphorylation of its downstream substrates RPS6 and 4EBP-1 (11, 12). These two downstream proteins, when phosphorylated, positively regulate the translation of proteins important for cell growth and replication (Figure 2) (1).

Currently, SEGA is considered among the astrocytic neoplasms by the WHO classification system and is described as a slowly growing tumor composed of "ganglioid astrocytes". Earlier studies concerning the origin of SEGA supported the current classification of this tumor as a variant of astrocytoma due to a lack of significant neuronal specific marker expression and fairly consistent presence of GFAP (13). Tumors found to be GFAP negative in these early studies were exclusively found in patients that also had tuberous sclerosis $(13,14)$. This interesting finding was hypothesized to be the result of specific gene mutations in tuberous sclerosis, which may result in an inability to produce GFAP (13). Later studies, including the data presented here, have shown variable presence of both glial and neuronal specific markers in SEGAs with and without TSC mutations (15). Thus, the exact cell of origin for SEGAs is debatable since the neoplasms demonstrate evidence of divergent differentiation despite their mainly astrocytic appearance (15-17).

While most SEGAs are easy to recognize on morphological grounds, some larger tumors or smaller samples may be diagnostically challenging and may raise other possibilities such as "gemistocytic astrocytoma" or pleomorphic xanthoastrocytoma. In order to determine the practical diagnostic value in identifying the mutated protein and aid in differential diagnosis, we analyzed the expression of tuberin and hamartin proteins in 9 patients with SEGA diagnosed within our institution between 1996 and 2010 (Table I). In addition, we evaluated the immunohistochemical expression of phosphorylated RPS6 and 4EBP1 regulatory proteins that are downstream to the hamartin-tuberin heterodimer in the mTOR pathway. Finally, we analyzed a set of common neuroepithelial and tumor-associated markers such as isocitrate dehydrogenase 1 and 2 (IDH1 and IDH2) mutations shown to be common in infiltrating astrocytomas.

\section{MATERIAL and METHODS}

Patients- We have searched the department of pathology archives for any patient diagnosed with subependymal giant cell astrocytoma (SEGA) between 1996 and 2010. Inclusion criteria for patients in the study were a previous diagnosis of SEGA with sufficient tumor tissue and clinical information. Consultation cases without available paraffin tissue, small samples and cases without sufficient clinical information were excluded. Appropriate permission for the study was obtained from the Committee for Human Research (CHR) of our institution (CHR no 10-00028).

Immunohistochemistry - Paraffin embedded tissue blocks were collected from the division of Neuropathology and 1 referred case from another institution (patient \#9). 4-6 micron thick tissue sections were cut from the tissue blocks and applied to slides. The tissue was deparaffinized in xylene using three changes for 5 minutes each. Sections were hydrated gradually through graded alcohols: washed in $100 \%$ ethanol twice for 10 minutes each, then $95 \%$ ethanol twice for 10 minutes each. Finally, the tissue was washed in deionized $\mathrm{H}_{2} \mathrm{O}$ for 1 minute with stirring and excess liquid was then aspirated from the slides. After antibody exposure, immunoperoxidase staining was performed utilizing a preformed avidin-biotinylated horseradish peroxidase complex as a detection reagent. The following antibodies were used on the prepared SEGA tissue specimens: Hamartin and Tuberin (polyclonal antibodies raised against N-terminus amino acids 1-300 of the respective human proteins, Santa Cruz Biotechnology Inc, dilutions 1:50 for 
Table I: Clinical features of patients with subependymal giant cell astrocytoma

\begin{tabular}{|c|c|c|c|c|c|c|c|c|c|}
\hline $\begin{array}{c}\text { Patient } \\
\#\end{array}$ & $\begin{array}{c}\text { Male/ } \\
\text { Female }\end{array}$ & $\begin{array}{c}\text { Age } \\
\text { at Dx }\end{array}$ & $\begin{array}{c}\text { Tuberous } \\
\text { sclerosis } \\
\text { confirmed } \\
\text { Y/N }\end{array}$ & $\begin{array}{c}\text { Comorbid } \\
\text { Tubers or } \\
\text { Nodules } \\
\text { Y/N }\end{array}$ & $\begin{array}{c}\text { Seizures } \\
\text { Y/N }\end{array}$ & Treatment & $\begin{array}{c}\text { Living after } \\
\text { F/U } \\
\text { Y/N }\end{array}$ & $\begin{array}{c}\text { F/U } \\
(\mathbf{m t h s})\end{array}$ & $\begin{array}{c}\text { Recurrence/ } \\
\text { Progression } \\
\text { Y/N }\end{array}$ \\
\hline 1 & $\mathrm{~F}$ & 17 & $\mathrm{Y}$ & $\mathrm{Y}$ & $\mathrm{Y}$ & STR+Rad & $\mathrm{Y}$ & 173 & $\mathrm{~N}$ \\
\hline 2 & $\mathrm{~F}$ & 1 & $\mathrm{Y}$ & $\mathrm{Y}$ & $\mathrm{Y}$ & $\mathrm{STR}$ & $\mathrm{N}$ & 26 & $?$ \\
\hline 3 & $\mathrm{~F}$ & 6 & $\mathrm{Y}$ & $\mathrm{Y}$ & $\mathrm{Y}$ & $\mathrm{GTR}$ & $\mathrm{Y}$ & 128 & $\mathrm{~N}$ \\
\hline 4 & $\mathrm{~F}$ & 8 & $\mathrm{~N}$ & $\mathrm{~N}$ & $\mathrm{~N}$ & $\mathrm{GTR}$ & $\mathrm{Y}$ & 94 & $\mathrm{~N}$ \\
\hline 5 & $\mathrm{M}$ & 7 & $\mathrm{Y}$ & $\mathrm{Y}$ & $\mathrm{Y}$ & $\mathrm{STR}$ & $\mathrm{Y}$ & 93 & $\mathrm{~N}$ \\
\hline 6 & $\mathrm{M}$ & 29 & $\mathrm{~N}$ & $\mathrm{~N}$ & $\mathrm{~N}$ & $\mathrm{STR}$ & $\mathrm{Y}$ & 76 & $\mathrm{Y}$ \\
\hline 7 & $\mathrm{M}$ & 18 & $\mathrm{Y}$ & $\mathrm{Y}$ & $\mathrm{Y}$ & $\mathrm{STR}$ & $\mathrm{Y}$ & 72 & $\mathrm{Y}$ \\
\hline 8 & $\mathrm{M}$ & 4 & $\mathrm{Y}$ & $\mathrm{Y}$ & $\mathrm{Y}$ & STR & $\mathrm{Y}$ & 67 & $\mathrm{Y}$ \\
\hline 9 & $\mathrm{M}$ & 57 & $\mathrm{Unk}$ & $\mathrm{Unk}$ & $\mathrm{N}$ & $\mathrm{Unk}$ & $\mathrm{Unk}$ & $\mathrm{Unk}$ & Unk \\
\hline
\end{tabular}

Table I shows clinical information pertaining to all 9 patients from which our SEGA specimens were collected. The male: female ratio was 5:4 with an age at diagnosis range of 1 to 57 years old. Tuberous sclerosis gene mutations were found in $6 / 9$ patients, while 2 of the 9 patients were found to have normal genes and patient 9 status was yet to be determined. All patients who tested positive for tuberous sclerosis gene mutations were found to have either comorbid cortical or subependymal nodules and tubers, while the two patients testing negative for the gene mutations had no comorbid findings. Those who tested positive for gene mutations also experienced seizures as a primary symptom while those who tested negative did not have seizures. Patient treatment information included subtotal resection with radiosurgery (STR+Rad), subtotal resection alone (STR) or gross total resection alone (GTR). Follow-up time (F/U) varied from 26 to 173 months with only one confirmed fatality with patient 2 . Confirmed recurrence or progression was confirmed in 3 of the 9 patients. Unk indicates unknown at this time.

hamartin, 1:50 for tuberin), $P$-4E-BP1 (monoclonal antibody raised against a synthetic phosphopeptide of mouse $4 \mathrm{E}-$ BP1, Cell Signaling Technologies, dilution 1:800), RPS6-P (polyclonal antibody raised against human phosphorylated S6 ribosomal protein, Cell Signaling Technologies, dilution 1:200), neurofilament protein (Sigma Chemicals, 1:20.000), synaptophysin (DAKO, 1:150), CD34 (Novocastra, 1:400), Olig-2 (IBL Co., 1:400), Ki67/MIB-1 (DAKO, 1:1000), and GFAP (DAKO, 1:3000). Pepsin treatment of slides was also performed for a batch with GFAP antibody staining.

Immunostaining results were subjectively evaluated on a scale from 0 to +3 based on quartiles. 0 indicates no visible staining in tumor, +1 indicates positive staining in less than a quarter of tumor cells, +2 indicates positivity in up to half of tumor cells, and $3+$ indicates strong positive staining in more than half of tumor cells. Staining results for Ki-67 was based on counting 1000 cells in the area of the tumor perceived to have the highest number of positively stained nuclei.

PCR analysis of IDH1 and IDH2 genes-formalin fixed, parafin embedded (FFPE) specimens were micro dissected to isolate tumor cells (when necessary), deparaffinized, digested (in a $56^{\circ} \mathrm{C}$ water bath for a minimum of 48 hours) and extracted using Qiagen DNA Mini Kit. DNA was quantified using a Nanodrop spectrophotometer. PCR was subsequently performed on an ABI 9700 thermocycler in a $20 \mathrm{uL}$ total volume reaction containing: $200 \mathrm{ng}$ DNA; $1 \mathrm{x}$ Roche 480 Probes Master $\mathrm{Mix}^{\circ} ; 0.30 \mu \mathrm{M}$ primers [IDH1 Exon 2 (Forward: TATTCTGGGTGGCACGGTCT, Reverse: GGTCTTTAAAGGTTGAACATA CAC); IDH2 Exon 4 (Forward: GCTGCAGTGGGACC ACTATT, Reverse: GAGACGTC ATGTTC CGGTGT)]. PCR cycling conditions were constructed as follows: 1 . Denaturing at $95^{\circ} \mathrm{C}$ for $2 \mathrm{~min}$., 2.35 cycles including $95^{\circ} \mathrm{C}$ for $0.5 \mathrm{~min}, 56^{\circ} \mathrm{C}$ for $0.5 \mathrm{~min}, 72^{\circ} \mathrm{C}$ for $0.5 \mathrm{~min}$, and extension at $72^{\circ} \mathrm{C}$ for 7 min., 3. Cooling at $4^{\circ} \mathrm{C}$ on hold setting. PCR products were then purified using Affymetrix/usb ExoSAP-IT (Santa Clara, CA). Specimen was then diluted out 1:3 with highgrade water. Cycle sequencing was subsequently performed using ABI Big Dye Terminator v1.1 Cycle Sequencing Kit (Life Technologies, Carlsbad, CA) in a 10uL reaction using: $1.0 \mu \mathrm{l}$ Big Dye Terminator v1.1, $0.5 \mu \mathrm{l}$ primer (10 pmol/ $\mu \mathrm{l}$ working concentration), and $1.0 \mu \mathrm{l}$ amplicon; on an $\mathrm{ABI}$ 9700 thermocycler. Big Dye cycling conditions were constructed as follows: 1 . Hold for $1 \mathrm{~min}$ at $96^{\circ} \mathrm{C}$., 2.25 cycles including $96^{\circ} \mathrm{C}$ for $10 \mathrm{sec}, 50^{\circ} \mathrm{C}$ for $5 \mathrm{sec}$, and $60^{\circ} \mathrm{C}$ for 1 min. 3. Hold at $4^{\circ} \mathrm{C}$. Big Dye ${ }^{\circ}$ Terminator reaction products were purified using Princeton Separations CENTRI-SEP spin columns (Princeton Separations, Adelphia, NJ) and subsequently run on an ABI 3130 sequencer for analysis. 


\section{RESULTS}

There were 5 male and 4 female patients with a median age at diagnosis of 16 years (range: 1 to 57 years; see Table I). Tuberous sclerosis gene mutations were confirmed in six of the nine patients, while two patients were found to have normal TSC genes and the genetic status of patient $\# 9$ was pending at the time of this report. All patients who tested positive for tuberous sclerosis gene mutations were found to have either comorbid cortical or subependymal nodules and tubers, while the two patients testing negative for the gene mutations had no comorbid findings (Figure 1). Those who tested positive for gene mutations also experienced seizures as a primary symptom while those who tested negative did not have seizures. Additional clinical symptoms observed include headache in patients $1,2,5$, and 6 , nausea and vomiting in patients 1,2 and 5, weakness and malaise in patient 1 , visual changes in patients 1 and 6, and incontinence in patient 2. Details of clinical information were not available for patient \#9 at the time of this report. One patient underwent subtotal resection with radiosurgery (STR+Rad), 5 were treated with subtotal resection alone (STR) and 3 had gross total resection (GTR). Follow-up time (F/U) varied from 26 to 173 months with only one confirmed fatality. Patient \#2 died after STR and 26 months follow-up. Recurrence or progression was observed in 3 of the 9 patients. All recurrences were in the form of newly developed, radiologically confirmed solid lesions. Time to recurrence was 1 year for two of the patients and 5 years for the other.

\section{Pathological features:}

Histological evaluation was performed by two of the authors (BB, TT). All tumors had diagnostic features of SEGAs according to WHO criteria. The tumors were predominantly composed of polygonal tumor cells resembling gemistocytes within a rich but variably fibrillar background. All tumors also harbored more spindled cells with prominent processes and occasional larger cells resembling ganglia. The larger cells had enlarged nuclei with prominent nucleoli. Scattered mitotic figures up to 2 per 10 high magnification fields were seen in almost all cases. Scattered small lymphocytic infiltrates and rare isolated mast cells were recognized in all cases. All of the cases had sufficient tissue for diagnosis and we did not have any tumor where there was uncertainty in diagnosis because of small tissue samples or ambiguous morphology.

Hamartin and tuberin expression was found to be relatively decreased in SEGA specimens compared to control tissue (Table II, Figure 2). RPS6 and 4EBP1 expression was found to be greater in SEGA specimens compared to control (Table II, Figure 2). GFAP was strongly positive in only half of the cases (Table II, Figure 3). Synaptophysin was positive in all tumors. Staining for CD34 (a marker often observed in well differentiated glio-neuronal tumors) and Olig2 (a nuclear

Table II: Immunohistochemical results of subependymal giant cell astrocytomas

\begin{tabular}{|l|c|c|c|c|c|c|c|c|c|}
\hline & GFAP & SYN & OLIG2 & Ki67 & CD34 & Ham & Tub & RPS6-P & P-4EBP-1 \\
\hline Case 1 & Pos (weak) & Pos & Neg & $2 \%$ & Neg & $2+$ & $2+$ & $1+$ & $3+$ \\
\hline Case 2 & Pos & Pos & Neg & $2 \%$ & Neg & $2+$ & $1+$ & $2+$ & $2+$ \\
\hline Case 3 & Neg & Pos & Neg & $2 \%$ & Neg & $1+$ & $1+$ & $1+$ & $2+$ \\
\hline Case 4 & Pos & Pos & Neg & $2 \%$ & Neg & $2+$ & $2+$ & $1+$ & $3+$ \\
\hline Case 5 & Pos & Pos & Neg & $4 \%$ & Neg & $1+$ & $1+$ & $1+$ & $1+$ \\
\hline Case 6 & Neg & Pos & Neg & $2 \%$ & Neg & $1+$ & $2+$ & $1+$ & $2+$ \\
\hline Case 7 & Neg & Pos & Neg & $2 \%$ & Neg & $1+$ & $2+$ & $2+$ & $3+$ \\
\hline Case 8 & Pos & Pos & Neg & $2 \%$ & Neg & $1+$ & $1+$ & $1+$ & $2+$ \\
\hline Case 9 & Pos & Pos & Neg & $8 \%$ & Neg & $2+$ & $2+$ & $2+$ & $2+$ \\
\hline Control 1 & & & & & & $3+$ & $3+$ & 0 & 0 \\
\hline Control 2 & & & & & & $3+$ & $3+$ & 0 & 0 \\
\hline
\end{tabular}

Table II shows immunohistochemistry results for all 9 SEGA specimens and the 2 non-pathological controls (from recent autopsy archives). Strong GFAP positivity was observed in 5 specimens with weak staining of 1 specimen and negative staining of the remaining 3 SEGAs. Synaptophysin was found to be positive in all 9 specimens while Olig2 and CD34 were found to be entirely negative in all specimens. Ki67 staining of the 9 SEGAs showed a low proliferation rate, which ranged from $2 \%$ to $8 \%$. SEGA staining for hamartin, tuberin, RPS6-P, and P-4EBP-1 were subjectively rated on a scale from 0 to $3+$ based on comparison with control staining. Hamartin and tuberin staining of all 9 SEGAs showed decreased intensity (range $1+$ to $2+$ ) when compared to control (3+). RPS6-P and P-4EBP-1 staining of all 9 SEGAs showed increased intensity (range $1+$ to $2+$ ) when compared to control (0). 
marker present in most gliomas) were entirely negative in all tumor cells (Table II, Figure 3). All of the tumors stained with the neurofilament antibody were predominantly negative except for focal neurofilament positivity along the periphery where the tumors have an indistinct border with the neuropil. Ki-67 (MIB-1) showed a low proliferation rate ranging from $2 \%$ to $8 \%$ (only one case at $8 \%$ ) supporting the indolent growth pattern of these tumors. The tumor with the highest Ki-67 labeling index had no evidence of recurrence or aggressive growth.

PCR analysis for mutations of IDH1 and IDH2 (often present in low grade infiltrating gliomas) were entirely negative in all tumor cells.

\section{DISCUSSION}

Our study aimed at using the recently developed antibodies for hamartin and tuberin as adjuncts to pathological as well as molecular diagnosis. We had initially hoped that it would be possible to determine the missing protein at the immunohistochemical level to aid in the recognition of patients with TSC. Our results suggest that staining for either hamartin or tuberin is unlikely to be of diagnostic value due to positivity in almost all tumors and normal tissues, even if the expression is relatively decreased in SEGA as expected. It is also of interest that even in the setting of TSC1 or TSC2 gene mutations, the protein is unlikely to be entirely absent from SEGA cells, thereby negating the diagnostic value of detecting the gene products. An interesting observation with these antibodies was the fact that two of the SEGAs without either TSC1 or TSC2 mutations had near-identical immunohistochemical staining profile with respect to hamartin and tuberin. These results may imply technical challenges, but also suggest that the expression of these proteins in SEGAs is regulated in a more complex way than we presumed.

One possible explanation for presence of weakly positive immunostaining includes inactivation of the TSC heterodimer by tuberin phosphorylation by Akt (18) or Erk (19) in cases without TSC gene mutations. Both Akt and Erk kinases are located upstream of the TSC complex and are known to phosphorylate tuberin (TSC-2), which is thought to inhibit the GTPase enhancing activity resulting in mTOR activation (Figure 4). Therefore, activation of either of these two upstream kinases may result in mTOR dysregulation similar to that seen with TSC gene mutations. More specifically, it has previously been shown that Erk

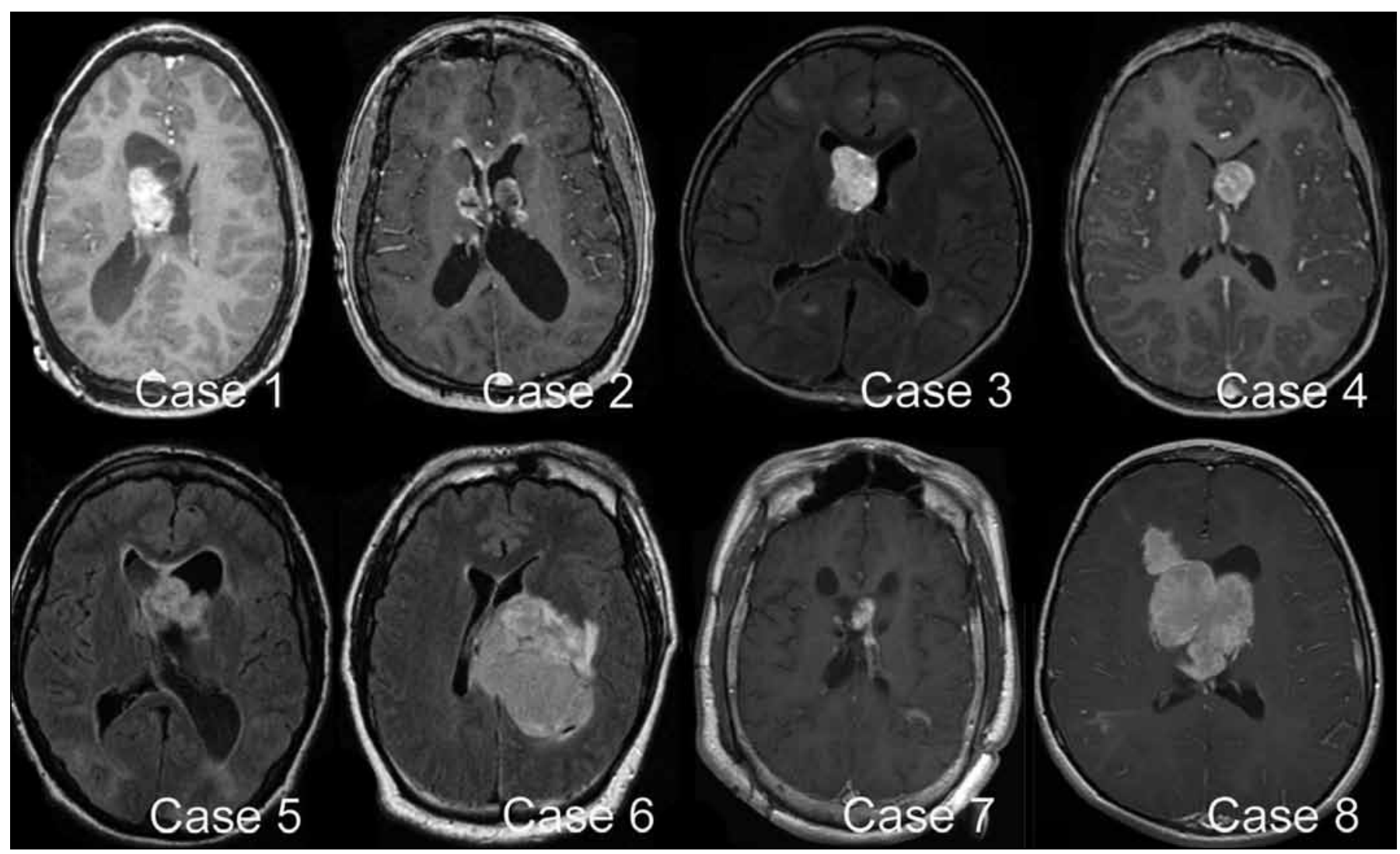

Figure 1: Pre-operative contrast enhanced T1-weighted MR images of patients with SEGA. Cases 1-8. Top Row: Cases 1-4 from left to right respectively. Bottom Row: Cases 5-8 from left to right respectively. 


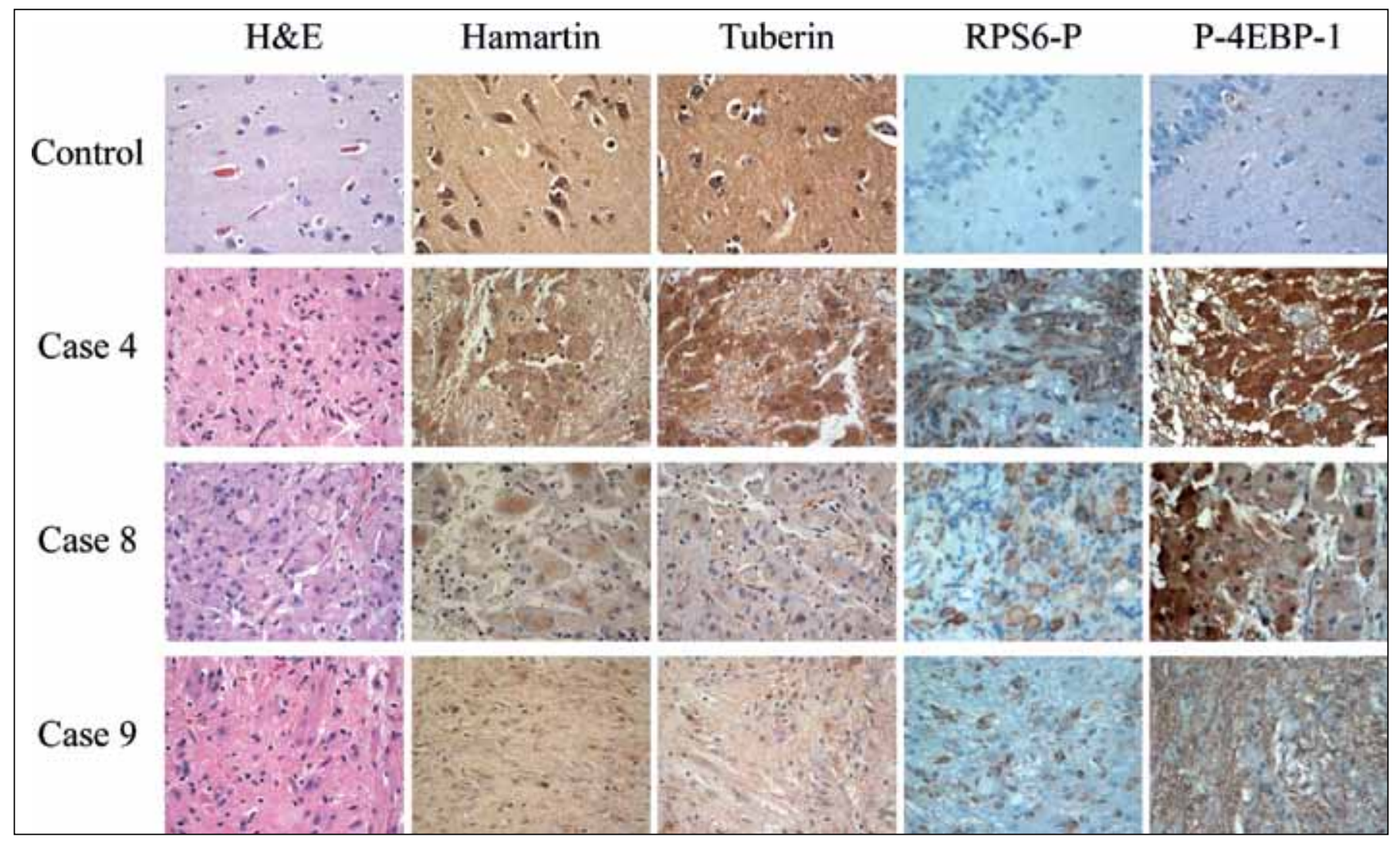

Figure 2: Immunohistochemical findings in SEGA and normal tissue controls for hamartin, tuberin, RPS6-P, and P-4EBP-1 antibodies. Hamartin and tuberin antibody staining of SEGA specimens show only slightly decreased intensity compared to control staining when analyzed as a group. However, as seen in figure, they were not helpful in individual cases to determine whether there was a loss of the protein in SEGAs. RPS6-P and P-4EBP-1 antibody staining of SEGA specimens show significant increased intensity compared to normal controls, suggesting activation of the pathways downstream to mTOR.

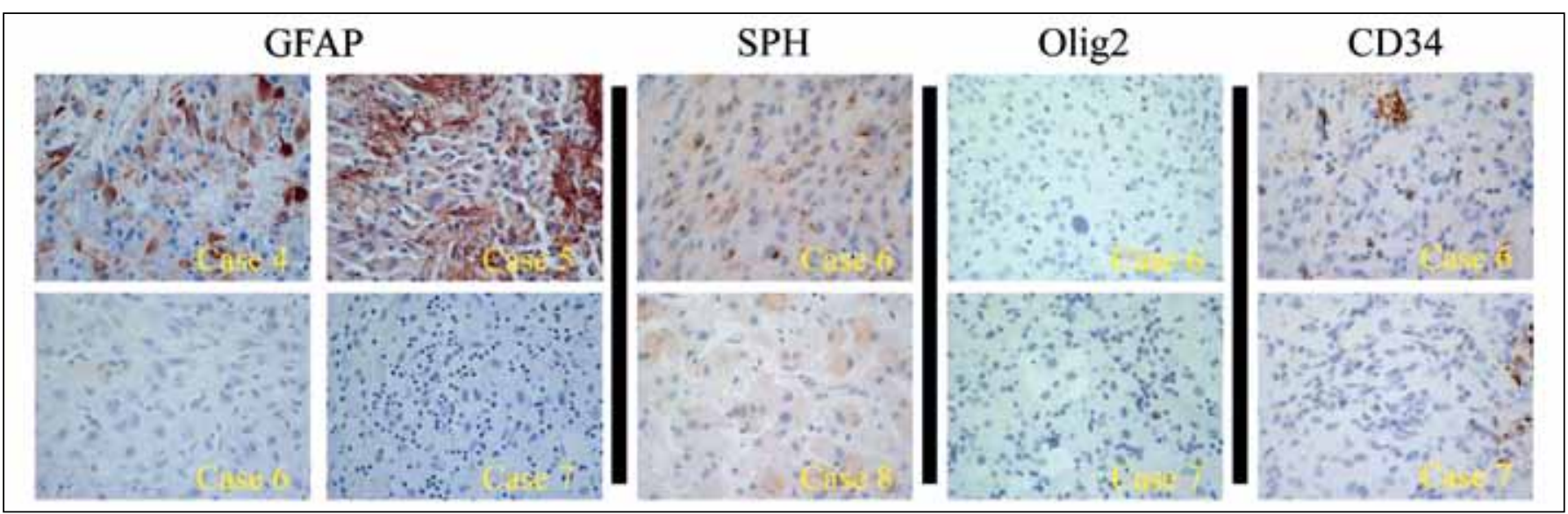

Figure 3: Immunohistochemical staining of SEGA specimens with GFAP, synaptophysin, Olig2, and CD34. The first panel of 4 images shows GFAP staining with variable staining in different tumors: Top two images show positive staining while the bottom two show essentially negative staining with the GFAP antibody. All negative stains were repeated to confirm the staining intensity. The second panel shows two representative images of the weak synaptophysin (SPH) staining found in all tumors. Panel three shows two representative images of negative Olig2 staining, which was consistent in all 9 SEGAs. Panel four shows two representative images of negative CD34 staining with positive staining in the vascular endothelium as internal control, which was also consistent in all tumors. 


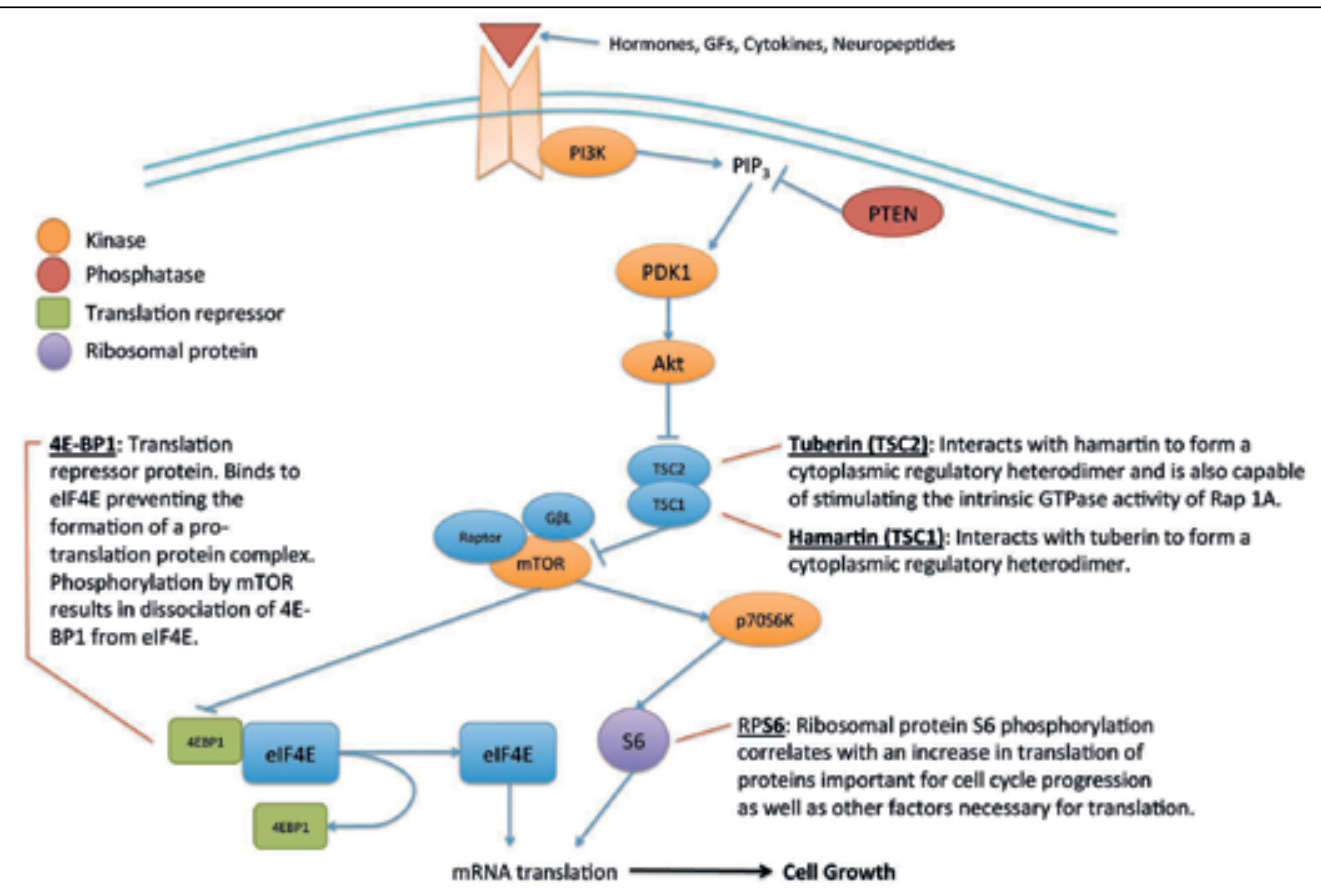

Figure 4: A schematic depiction of the signal transduction pathway including mTOR, TSC-1/TSC-2 regulatory complex, and downstream translation-modifying proteins RPS6 and 4EBP-1 believed to be involved in the growth of SEGAs. Abbreviations: PI3K: Phosphoinositide 3-kinase, PDK1: Pyruvate dehydrogenase kinase isozyme 1, PTEN: phosphatase and tensin homolog protein, mTOR: mammalian target of rapamycin.

activation is present in all SEGAs and may also play a crucial role in tumor formation in tuberous sclerosis patients (19). Our data support the observations of other groups, which have shown that LOH is uniquely sporadic in SEGAs when compared to other tumors in TSC patients (3-5).

The increased RPS6 and 4EBP1 immunostaining further confirms the activation of the mTOR pathway and the possible role these molecules may have in the growth of SEGAs, as previously suggested (1). This finding also implies that hamartin and tuberin detected on immunohistochemical studies are most likely dysfunctional molecules unable to inhibit activation of the mTOR pathway. Our results further justify the use of Rapamycin to control growth subtotally resected or non-resectable SEGAs (20-22).

In our experience, Olig-2 antibody has emerged as a quite reliable and easily interpretable marker of glial differentiation in diagnostic surgical neuropathology (23). In some instances where GFAP was not helpful, Olig-2 has greatly helped in the recognition of glial differentiation in tumors (unpublished observations). We have also presumed that Olig-2 could be another helpful marker in tumors where GFAP has been negative, but our results demonstrate complete absence of this nuclear stain in SEGAs. This finding is quite interesting, when combined with the results of the GFAP antibody that some SEGAs have less glial and more neuronal phenotype, at least on immunohistochemical grounds.

While some of the immunohistochemical markers have come under scrutiny and suspicion in terms of their validity in showing neuronal differentiation, positive staining with neuronal markers along with negative GFAP and Olig-2 stains supports the suggestion of an ambiguous differentiation in SEGA (Figure 3). It is possible that the staining results obtained in our study reflect a technical problem or an aberration in the fixation pattern of paraffin blocks giving a false negative result. To account for this possibility, we have repeated all negative cases and have used pepsin digestion as an alternate method if the stain was still negative after two trials. In addition, two of the pathology specimens included small fragments of neuropil within the blocks, which showed strong unequivocal GFAP staining. While it is still possible that technical mishaps may account for the staining results in rare cases, we believe that GFAP staining can be truly negative in some SEGAs. Our results are in agreement with Ess and colleagues who found GFAP positive staining in $50 \%(4 / 8)$ of the SEGAs they analyzed (15). The results of their work illustrated the inconsistent presence of both glial and neuronal developmental markers in all their tumors and suggested SEGAs may develop from postnatally active neuroglial progenitor cells 
(15). Buccoliero et al. also showed variable staining with synaptophysin between different cell types in $8 / 9$ of the tumors they tested, while we found $100 \%$ (9/9) positive staining in our specimens with variable staining observed between the three primary cell types. Additionally, we also found all of our tumors to be entirely negative for CD34 (which is often positive in well-differentiated glio-neuronal tumors) and the tumors to be mostly negative for NF. This supports the results of You et al. (24) who found all of their tumors $(8 / 8)$ to be negative for NF, but is at odds with the findings of Sharma et al., (17) who found positive staining in 15/15 SEGA specimens. This may relate to the type of antibody used in the studies.

Our observations as well as observations of others mentioned above imply that SEGA may be considered more of a glioneuronal neoplasm than a pure astrocytic tumor in a broader sense. Further evidence and more conclusive data are required to make a more definitive statement about the actual cell of origin in SEGAs and their appropriate place in the WHO classification scheme.

In addition to immunohistochemical analysis, we also investigated the possible presence of the isocitrate dehydrogenase gene (IDH1 and IDH2) mutations, which have recently, been shown to be present in $70-80 \%$ of diffuse low-grade infiltrating gliomas (25-28). As of today, the tumors that have been found to carry this mutation were predominantly infiltrating neoplasms, while circumscribed tumors such as pilocytic astrocytoma had wild-type genes (28). IDH1 is the most common gene found mutated, and the most frequent mutation found is $\mathrm{R} 132 \mathrm{H}$ (CGT to CAT) in exon 4 (83-91\%) (27). In gliomas testing negative for the IDH1 mutation, $\sim 18 \%$ test positive for IDH2 mutation at exon 4(29). In an effort to add additional insight into the genetic makeup of SEGA, we performed sequence analysis of exon 4 in IDH1 and IDH2 for each of our 9 SEGA specimens. We found that all specimens (9/9) were negative for IDH1 and IDH2 mutations at exon 4. Our results support the research of Balss and colleagues who found the IDH1 mutation to be absent in all of their SEGA specimens tested (25). We have also shown that SEGAs are negative for the IDH2 mutation at exon 4. This finding is consistent with the impression that infiltrating gliomas typically carry the IDH mutations, while almost all of the non-infiltrative gliomas are wild-type.

\section{DISCLOSURE/CONFLICT of INTEREST}

We have no conflict of interest to declare.

\section{REFERENCES}

1. Chan JA, Zhang H, Roberts PS, Jozwiak S, Wieslawa G, Lewin-Kowalik J, Kotulska K, Kwiatkowski DJ: Pathogenesis of tuberous sclerosis subependymal giant cell astrocytomas: biallelic inactivation of TSC1 or TSC2 leads to mTOR activation. J Neuropathol Exp Neurol 2004, 63:1236-1242

2. Povey S, Burley MW, Attwood J, Benham F, Hunt D, Jeremiah SJ, Franklin D, Gillett G, Malas S, Robson EB: Two loci for tuberous sclerosis: one on 9q34 and one on 16p13. Ann Hum Genet 1994, 58:107-127

3. Henske EP, Scheithauer BW, Short MP, Wollmann R, Nahmias J, Hornigold N, van Slegtenhorst M, Welsh CT, Kwiatkowski DJ: Allelic loss is frequent in tuberous sclerosis kidney lesions but rare in brain lesions. Am J Hum Genet 1996, 59:400-406

4. Jansen FE, Notenboom RG, Nellist M, Goedbloed MA, Halley DJ, de Graan PN, van Nieuwenhuizen O: Differential localization of hamartin and tuberin and increased S6 phosphorylation in a tuber. Neurology 2004, 63:1293-1295

5. Tabuchi S, Takigawa H, Oka A, Mizuguchi M, Horie Y, Watanabe T: Subependymal giant cell astrocytoma with positive tuberin expression-case report. Neurol Med Chir 2003, 43:616618

6. Jiang WG, Sampson J, Martin TA, Lee-Jones L, Watkins G, Douglas-Jones A, Mokbel K, Mansel RE: Tuberin and hamartin are aberrantly expressed and linked to clinical outcome in human breast cancer: the role of promoter methylation of TSC genes. Eur J Cancer 2005, 41:1628-1636

7. Jozwiak J, Jozwiak S, Wlodarski P: Possible mechanisms of disease development in tuberous sclerosis. Lancet Oncol 2008, 9:73-79

8. Rosner M, Fuchs C, Siegel N, Valli A, Hengstschlager M: New insights into the role of the tuberous sclerosis genes in leukemia. Leuk Res 2009, 33:883-885

9. Lee DF, Hung MC: All roads lead to mTOR: integrating inflammation and tumor angiogenesis. Cell Cycle 2007, 6: 3011-3014

10. Rosner M, Hanneder M, Siegel N, Valli A, Fuchs C, Hengstschlager M: The mTOR pathway and its role in human genetic diseases. Mutat Res 2008, 659:284-292

11. Beretta L, Svitkin YV, Sonenberg N: Rapamycin stimulates viral protein synthesis and augments the shutoff of host protein synthesis upon picornavirus infection. J Virol 1996, 70:8993-8996

12. Fingar DC, Salama S, Tsou C, Harlow E, Blenis J. Mammalian cell size is controlled by mTOR and its downstream targets S6K1 and 4EBP1/eIF4E. Genes Dev 2002, 16:1472-1487

13. Bonnin JM, Rubinstein LJ, Papasozomenos SC, Marangos PJ: Subependymal giant cell astrocytoma. Significance and possible cytogenetic implications of an immunohistochemical study. Acta Neuropathol 1984, 62:185-193

14. Velasco ME, Dahl D, Roessmann U, Gambetti P: Immunohistochemical localization of glial fibrillary acidic protein in human glial neoplasms. Cancer 1980, 45:484-494

15. Ess KC, Kamp CA, Tu BP, Gutmann DH: Developmental origin of subependymal giant cell astrocytoma in tuberous sclerosis complex. Neurology 2005, 64:1446-1449 
16. Buccoliero AM, Franchi A, Castiglione F, Gheri CF, Mussa F, Giordano F, Genitori L, Taddei GL: Subependymal giant cell astrocytoma (SEGA): Is it an astrocytoma? Morphological, immunohistochemical and ultrastructural study. Neuropathology 2009, 29:25-30

17. Sharma MC, Ralte AM, Gaekwad S, Santosh V, Shankar SK, Sarkar C: Subependymal giant cell astrocytoma--a clinicopathological study of 23 cases with special emphasis on histogenesis. Pathol Oncol Res 2004, 10:219-224

18. Han S, Santos TM, Puga A, Roy J, Thiele EA, McCollin M, Stemmer-Rachamimov A, Ramesh V: Phosphorylation of tuberin as a novel mechanism for somatic inactivation of the tuberous sclerosis complex proteins in brain lesions. Cancer Res 2004, 64:812-816

19. Jozwiak J, Grajkowska W, Kotulska K, Jozwiak S, Zalewski W, Zajaczkowska A, Roszkowski M, Slupianek A, Wlodarski P: Brain tumor formation in tuberous sclerosis depends on Erk activation. Neuromolecular Med 2007, 9:117-127

20. Franz DN, Leonard J, Tudor C, Chuck G, Care M, Sethuraman G, Dinopoulos A, Thomas G, Crone KR: Rapamycin causes regression of astrocytomas in tuberous sclerosis complex. Ann Neurol 2006, 59:490-498

21. Koenig MK, Butler IJ, Northrup H: Regression of subependymal giant cell astrocytoma with rapamycin in tuberous sclerosis complex. J Child Neurol 2008, 23:1238-1239

22. Krymskaya VP, Goncharova EA: PI3K/mTORC1 activation in hamartoma syndromes: therapeutic prospects. Cell Cycle 2009, 8:403-413
23. Otero JJ, Rowitch D, Vandenberg S: OLIG2 is differentially expressed in pediatric astrocytic and in ependymal neoplasms. J Neurooncol 2010, 104:423-438

24. You H, Kim YI, Im SY, Suh-Kim H, Paek SH, Park SH, Kim DG, Jung HW: Immunohistochemical study of central neurocytoma, subependymoma, and subependymal giant cell astrocytoma. J Neurooncol 2005, 74:1-8

25. Balss J, Meyer J, Mueller W, Korshunov A, Hartmann C, von Deimling A: Analysis of the IDH1 codon 132 mutation in brain tumors. Acta Neuropathol 2008, 116:597-602

26. Watanabe T, Nobusawa S, Kleihues P, Ohgaki H: IDH1 mutations are early events in the development of astrocytomas and oligodendrogliomas. Am J Pathol 2009, 174:1149-1153

27. Watanabe T, Vital A, Nobusawa S, Kleihues P, Ohgaki H: Selective acquisition of IDH1 R132C mutations in astrocytomas associated with Li-Fraumeni syndrome. Acta Neuropathol 2009, 117:653-656

28. Yan H, Parsons DW, Jin G, McLendon R, Rasheed BA, Yuan W, Kos I, Batinic-Haberle I, Jones S, Riggins GJ, Friedman H, Friedman A, Reardon D, Herndon J, Kinzler KW, Velculescu VE, Vogelstein B, Bigner DD: IDH1 and IDH2 mutations in gliomas. New Eng J Med 2009, 360:765-773

29. Kim YH, Nobusawa S, Mittelbronn M, Paulus W, Brokinkel B, Keyvani K, Sure U, Wrede K, Nakazato Y, Tanaka Y, Vital A, Mariani L, Stawski R, Watanabe T, De Girolami U, Kleihues P, Ohgaki H: Molecular classification of low-grade diffuse gliomas. Am J Pathol 2010, 177:2708-2714 